\title{
Geochemical features of the gabbroids of the Khairkhan massif (Lake Zone of Western Mongolia)
}

\author{
K.R KURUMSHIEVA ${ }^{1}$, A.V. VISHNEVSKY ${ }^{2}$, \\ A.E. IZOKH ${ }^{3}$, I.F. GERTNER ${ }^{1}$ \\ ${ }^{1}$ Tomsk State University, Russia, kkurumsieva@gmail.com \\ ${ }^{2}$ Novosibirsk State University, Russia \\ ${ }^{3}$ Sobolev Institute of Geology and Mineralogy, Russia
}

Using the XRF and the ICP-MS method, samples of rocks of the Khairkhan layered pluton were analyzed.

According to the total alkalinity, the rocks belong to the normal series, according to the accumulation of total iron, they correspond to the tholeiite series. By the data of the ratio of $\mathrm{K}_{2} \mathrm{O}$ and $\mathrm{Na}_{2} \mathrm{O}$, the studied gabbroids correspond to formations of sodium specialization [1].

The distribution spectra of REE show a generally weak degree of REE differentiation $\left((\mathrm{La} / \mathrm{Sm})_{\mathrm{N}}\right.$ 0.5-2.18; $(\mathrm{La} / \mathrm{Yb})_{\mathrm{N}}$ $0.69-5.18)$. The rocks are characterized by a distinct positive $\mathrm{Eu}$ anomaly, which is more pronounced in the rocks of the layeres series $(\mathrm{Eu} / \mathrm{Eu} * 2.22-3.78)$ than in the marginal facies $(\mathrm{Eu} / \mathrm{Eu} * 1.23-1.86)$. This difference confirms the increased role of plagioclase fractionation in layered rocks. It should be noted that the REE spectra of layered rocks have a weak negative slope $\left((\mathrm{La} / \mathrm{Yb})_{\mathrm{N}} 2.19-5.18\right)$, which is more obvious for troktolites. Rocks of the marginal facies form almost horizontal spectra $\left((\mathrm{La} / \mathrm{Yb})_{\mathrm{N}}\right.$ 0.69-1.92) with concentrations from to 10 chondritic units.

On multielement spectra, the distribution curves are characterized by a weak negative slope, and in the HREE region they are practically flattened. The most important and interesting features of the distribution of trace elements are a strong positive $\mathrm{Sr}$ anomaly and a distinct relative depletion of $\mathrm{Th}, \mathrm{Nb}$ and $\mathrm{Zr}$ with a lower degree depletion of $\mathrm{U}$, Ta and $\mathrm{Hf}$ [1].

According to petrochemical parameters, the gabbroids of the Khairkhan massif are considered to be products of the sodium tholeiitic petrochemical series, and in terms of concentration and distribution features of REE and trace elements are close to the magmatism products of island-arc paleosystems. The geodynamic regime of the formation of this pluton is apparently associated with the subduction situation under the influence of the North Asian plume.

This study was supported by the Geochronological (Sm$\mathrm{Nd}$ and $\mathrm{Rb}$-Sr isotopes) research has been carried out within the grant of the Russian Science Foundation (project № 1817-00240).

[1] Izokh et al (2019) IOP Conference 319, 1-13. 